Original Research Paper

\title{
Analysis of Power Uprate in Nuclear Power Plants
}

\author{
${ }^{1}$ Alejandro Nuñez-Carrera, ${ }^{1}$ Ana Lidia Carreño-Padilla, \\ ${ }^{2}$ Erick Gilberto Espinosa-Martínez and ${ }^{1}$ Raúl Camargo-Camargo \\ ${ }^{1}$ Comisión Nacional de Seguridad Nuclear y Salvaguardias, Doctor Barragán 779, Col. Narvarte, México D.F., México \\ ${ }^{2}$ Área de Ingeniería en Recursos Energéticos, Universidad Autónoma Metropolitana-Iztapalapa, \\ Av. San Rafael Atlixco 186, Col. Vicentina, 09340 México D.F., México
}

Article history

Received: 07-10-2014

Revised: $15-01-2015$

Accepted: 24-06-2017

Corresponding Author: Erick Gilberto EspinosaMartínez

Área de Ingeniería en Recursos

Energéticos, Universidad Autónoma MetropolitanaIztapalapa, Av. San Rafael Atlixco 186, Col. Vicentina, 09340 México D.F., México Emil: yurihillel@gmail.com

\begin{abstract}
The three main strategies used by the utilities in order to obtain more benefits from the nuclear installations focused on electricity production and in order to satisfy their demand without carbon dioxide emissions are: (1) Power uprate, (2) plant life management and (3) plant life extension. Alone in the United States, the Nuclear Regulatory Commission has approved more than 140 Nuclear Power Plant (NPP) power uprates since 1977, which represent the equivalent of five new Nuclear Power Plants (NPPs). While in the rest of the world the NPP uprates represent the equivalent of two new NPP. This study is a compilation of the power uprate experience in the whole world and a discussion about important problems detected due to this process in Light Water Reactors (LWR), specifically for Boiling Water Reactors (BWR). The power uprate involves the reanalysis of many topics in order to assure that the safety operational margins are kept. The new radiological consequences, structural integrity of the systems, vibrations, core heat balance and thermal-hydraulics behavior under transient and accident conditions, are some of the aspects to be considered during power uprate processes. As special case the Laguna Verde Power Nuclear Power Plant (LVNPP) Extended Power Uprate (EPU) is presented, whose experience indicated that the steam dryer loads are crucial for uprates in BWR's.
\end{abstract}

Keywords: Power Uprates, Nuclear Power Plants, BWR

\section{Introduction}

The generation of electricity without carbon dioxide emission is one of main strategies against climate change, but the demand of electricity is increasing dramatically, in particular if we considered that the world population is increasing about $10 \%$ each ten years. Nowadays there is a high demand of fossil fuel with an important emission of gases to the atmosphere and the need to find environmentally sustainable way to provide energy with low sensitivity to price volatility is one of the main reason why the nuclear energy become in an important candidate to provide clean energy in the following years. However, the constructions of new Nuclear Power Plants (NPPs) represent a very important investment and take about four years.

The Chernobyl Accident in 1986 represented a critical point for the nuclear industry due to the construction of new NPP practically stopped and countries as Italy took the decision to close all the nuclear facilities related with electricity production. Strategies as stricter regulations were applied by the regulatory bodies in order to "assure the safety in nuclear installations". After Chernobyl accident, the power uprate represents one of the best option to obtain major benefits of the NPP due to the over regulation for the construction of new NPPs and the public opinion against nuclear energy, however plant owners began performing power uprates since 1970, in particular the Nuclear Regulatory Commission (NRC) of the United Stated approved the first uprate in September of 1977.

Following twenty year of experience, the regulatory bodies are working for relax the regulation and provide certainty to the investors without diminishing the safety and restart the construction of new NPP as one of the main strategies against climate change.

The process of increasing the licensed power level of a commercial NPP is called a power uprate. The power uprates are generally categorized based on the magnitude of the power increase and the methods used to achieve the increase. The utilities have been used power uprates as a way to generate more electricity from their Nuclear Power Plants (NPPs). The power uprated in NPPs is possible due the increment of amount of fissile material in the nuclear fuel and therefore is necessary the increment of feedwater and steam flow. For some power uprate, lower than $7 \%$, is not necessary do important modification in the NPPs, but for the extended power 
uprates the changes of important equipment as turbine, generator and main condenser among others is performed.

There are important economic benefits associated with the power uprate due to is possible the generation of more electricity in the same NPP, the cost of each refuel increase but the rest of the operational cost is almost the same that before the power uprate. However there are many aspects to be considered in this kind of project in order to assure the safe operational of the nuclear installations and these are highly dependent of the regulation in each country (Lundgren and Riess, 2007).

In general, both deterministic and probabilistic safety analyses are used to evaluate the impact of significant plant modifications such as power uprate. The deterministic acceptance criteria will be satisfied after plant modifications, the fact that the plant response could get closer to the acceptance limits for several safety variables suggests a potential increase of core damage frequency and other possible risk indicators such as departure from nucleate boiling ratio, large early release frequency (Kim et al., 2012). These authors carried out a quantitative evaluation of change in core damage frequency by postulated power uprate.

The power uprate involve some problems associated with the increase of steam and feedwater flow, for instance the occupational doses is impacted, in particular in Boiling Water Reactors (BWRs) where occupational exposure is about 50\% higher than a Pressurized Water Reactors (PWRs). Other identified problem associated with the power uprate is related with the acoustic load over the steam dryer in BWRs, where loose part can be generated as results of high cycle fatigue failure (Hambric et al., 2006). The excitation of mechanism of acoustic resonances has been studied in order to avoid severe vibrations and noise problems in nuclear reactor (Ziada and Shine, 1999; Ziada, 2010; NRC, 2004; Tulon, 2002). The alternative is a design of new steam dryer for extended power uprated conditions, to both decrease vibration levels in the steam lines and to solve a water-level measurement problem (Tulon, 2002)

The increase of the steam flow velocity implies the improvement of the in service inspection techniques in order to avoid excessive corrosion in some critical pipes is other important aspect to be considered during the operation after the uprate implementation. The power density of a nuclear reactor upon a power uprate would change immediately, followed by water chemistry variations due to enhanced radiolysis of water in the core and near-core regions. The impact of power uprate on the water chemistry of a commercial boiling water reactor was analyzed by Wang et al. (2008).

Due to the boom so important and acceptance of the power uprate in nuclear power plants around the world have now emerged advanced technological proposals and designs to improve core nuclear reactor performance, such as the use the MOX fuel in a BWR with extended power uprate (Ramírez et al., 2012), or thermal hydraulic analysis of dual-cooled annular nuclear fuel for OPR-1000 (Shin et al., 2012).
In this study we presents a compilation of the international experience related with the power uprated, the most important regulatory safety issues and problems related with this. Finally, a brief recompilation of the Extended Power Uprate (EPU) for Laguna Verde NPP is considered.

\section{Types of Power Uprates}

Power plant licensees have been adopting the power uprate as an efficient way to increase the thermal energy and the electrical output (Ferng, 2009). Currently a significant number of the nuclear power plants have plans for power uprate by larger or smaller amounts. In most cases this is an economic way of producing more electricity in a nuclear power plant and which has attracted interest due to increased electricity prices and the international position to generate electricity in a cleaner way.

Power uprates can be classified in three categories (IAEA, 2003): (1) Measurement uncertainty (recapture power uprates), (2) stretch power uprates and (3) extended power uprates.

\section{Measurement Uncertainty}

Measurement uncertainty are power increases less than $2 \%$ and are achieved by using enhanced techniques for calculating reactor power. This involves the use of state-ofthe-art devices to precisely measure feedwater flow to calculate reactor power. More precise measurements reduce the degree of uncertainty in the power level, which is used by analysts to predict the ability of the reactor to be safely shutdown under accident conditions.

\section{Stretch Power Uprates}

Stretch power uprates are typically up to $7 \%$ and usually involve changes to instrumentation settings. Stretch power uprates generally do not involve major plant modifications; this is especially true for boiling water reactor plants. In some limited cases, where plant equipment was operated near maximum capacity prior to the power uprate, more substantial changes may be required.

\section{Extended Power Uprates}

Extended power uprates are usually greater than stretch power uprates and have been approved for increases as high as $20 \%$. Extended power uprates usually require significant modifications to major pieces of plant equipment such as the high-pressure turbines, condensate pumps and motors, main generators and/or transformers.

\section{Safety Margins}

The power uprate involves the use of margins in plant design, safety analysis and plant operation. The use of margins should be balanced with adequate margin generation, i.e., margins that are obtained by using less conservative calculations (IAEA, 2004). The available 
capacity in safety margins in some of the operating NPPs are prompting nuclear utilities to request license modifications to enable operation at a higher power level, beyond the provisions of the original license. Such plant modifications require an in-depth safety analysis to evaluate the possible safety impact. The analysis must consider the core characteristics and the plant behavior, taking into account the capability of the Structures, Systems and Components (SSC), the reactor protection and safeguard systems set points.

Although the emphasis of the safety analysis is on a deterministic evaluation that safety criteria are met, concerns relating to overall plant safety and the risk impact of power uprates also require that the safety margins be evaluated with Probabilistic Safety Analysis (PSA) methods (Martin, 2012). This is necessary to support and supplement deterministic analysis, technical judgment and to enable risk informed decision making process. Not only power uprates have potential impact on safety but also other design changes, on fuel, SSC may influence the same safety parameters and associated margins.

According with the nuclear regulations, the design of the NPPs follows very strict general criteria and requires the performance of conservative safety analysis with at least $2 \%$ over the Current License Power (CLP) in order to assure that the operating point is far away from the safety limit. The safety margins of operating reactors and implications in NPPPs were discussed in IAEA (2004). Is well know that the power uprate implies the reduction of the safety margins, therefore the understanding the implications of the new power level on plant operation, plant design margins and licensing basis issues is critical to a successful program. This IAEA publication addresses the capabilities of and thermal-hydraulic computer codes, methods for safety margin evaluation and how safety margins can be utilized in the operation of NPPs and when some modifications, as the power uprates, are considered for them.

\section{The Status of the World Power Uprate in NPP}

The Table 1 shows the number of NPPs that have been approved by the NRC to operate under power uprate condition. The higher contribution about $47.3 \%$ is from the extended power uprate and the lower one is from the measure uncertainty recapture power uprate. The result of these power uprates is a gain of approximately 20,492.2 MWt (Megawatts thermal) or 6,823.7 MWe (Megawatts electric) at existing plants and if we considered the applications under review the gain is $23,586.8 \mathrm{MWt}$ or 7,863.2 MWe (Table 2).

In Europe there are 43 NPPs with 148 nuclear power reactors in operation that represents $172,214.0 \mathrm{MWe}$, which represents $16.5 \%$ of the total electricity production. Regarding to the power uprated, this represented an increment of $2,936 \mathrm{MWe}$, which corresponds to $2 \%$ of increment. These uprates have added generating capacity at existing plants of 8,745.7 MWe, so the power uprated in USand Europe represent the equivalent to seven new reactors of 1,200.0 MWe each one. In Asia the power uprate has not been implement yet, but is the next market for uprated (WEC, 2007).

Table 1. Power uprate in United States until 2012

\begin{tabular}{lllll} 
Type & Power total $(\mathrm{MWt})$ & Power total $(\mathrm{MWe})$ & Power uprate $(\%)$ & Number of reactors \\
\hline MUR & 2359.0 & 786.33 & 11.52 & 55 \\
SPU & 8499.2 & 2833.07 & 41.52 & 65 \\
EPU & 9612.0 & 3204.00 & 46.96 & 28
\end{tabular}

$\mathrm{SPU}=$ Stretch $; \mathrm{EPU}=$ Extended; MUR = Measurement Uncertainty Recapture

Table 2. Power uprate applications in the United States under review (NRC, 2013)

\begin{tabular}{|c|c|c|c|c|c|}
\hline Reactor name & $\%$ & MWt & MWe & Expected completion date & Type \\
\hline Browns Ferry 2 & 14.3 & 494.0 & 164.7 & TBD & $\mathrm{E}$ \\
\hline Browns Ferry 3 & 14.3 & 494.0 & 164.7 & TBD & E \\
\hline Browns Ferry 1 & 14.3 & 494.0 & 164.7 & TBD & E \\
\hline Monticello & 12.9 & 229.0 & 76.3 & 3rd Quarter 2013 & $\mathrm{E}$ \\
\hline Braidwood 1 & 1.6 & 58.4 & 19.5 & On Hold & MUR \\
\hline Braidwood 2 & 1.6 & 58.4 & 19.5 & On Hold & MUR \\
\hline Byron 1 & 1.6 & 58.4 & 19.5 & On Hold & MUR \\
\hline Byron 2 & 1.6 & 58.4 & 19.5 & On Hold & MUR \\
\hline Oconee 1 & 1.6 & 42.0 & 14.0 & On Hold & MUR \\
\hline Oconee 2 & 1.6 & 42.0 & 14.0 & On Hold & MUR \\
\hline Oconee 3 & 1.6 & 42.0 & 14.0 & On Hold & MUR \\
\hline McGuire 1 & 1.7 & 58.0 & 19.3 & April 2013 & MUR \\
\hline McGuire 2 & 1.7 & 58.0 & 19.3 & April 2013 & MUR \\
\hline Peach Bottom 2 & 12.4 & 437.0 & 145.7 & June 2014 & $\mathrm{E}$ \\
\hline Peach Bottom 3 & 12.4 & 437.0 & 145.7 & June 2014 & $\mathrm{E}$ \\
\hline Fermi 2 & 1.6 & 56.0 & 18.7 & November 2013 & MUR \\
\hline Total & & 3116.6 & 1038.9 & & \\
\hline
\end{tabular}

$\mathrm{E} \quad=$ Extended

MUR $=$ Measurement Uncertainty Recapture 
The utilities in Europe that are planning to implement power uprate within next few years are (Lundgren and Riess, 2007):

- $\quad$ Forsmark-3 (BWR) is planning 25\% uprate in 2014

- $\quad$ Ringhals-1 (BWR) is planning $11.9 \%$ power uprate (date not known)

On the other hand, Laguna Verde NPP (U1 and U2) are planning $20 \%$ power uprate in 2011 .

\section{Plan Life Extension (PLEX)}

Extension of reactor lifetimes from 40 to 60 years is enhancing the economic competitiveness of plants, while both ownership and operation of these is becoming concentrated. Financially, operators would sooner extend the life of their plants rather than decommissioning, an issue that is now more important than ever due to the current economic situation.

There are now 104 operating nuclear power reactors in the United States, with $30 \%$ coming to the end of their 40 years cycle. These plants now need approval by the NRC to continue operating by applying for a new operating license. This process is complex often taking years to complete. The NRC guidelines must be followed giving rise to predicaments such as replacing nuclear components and the obsolescence of equipment, as well as degradation issues with underground piping and medium voltage cables. Other important point to consider in the PLEX is the refurbishment requirements and timing; fuel characteristic modifications and fuel cycle delays; decommissioning and waste disposal. The economic assessment is needed to analyze the impacts of lifetime extension versus early shut-down followed (or not) by the construction of a new nuclear power plant on capital requirements, future financial liabilities and levelised electricity generation costs (NEA, 2006).

In Europe the situation related with the aging of the power plant is very similar, the coal and NPPs account more than $70 \%$ of all the power plant that will be at least 30 years old in 2020 and the replacement more than $50 \%$ of the current electricity production installation. The project underway as Flamanville in France, Olkiluoto 3 in Finland, Cernavoda 2 in Romania, Rostov 2 and Kalinin 4 in Russia, shows that the production of electricity using nuclear energy is one of the more important options in Europe to replace the coal capacity.

Extending the lifetime of nuclear power plants is becoming common practice. While applying for an extended operating license, most operators are planning technical improvements, safety upgrades and modification of fuel characteristics and performance as well as refueling patterns and lead times. If the extension of life of the NPP is not considered, in 2036 will be 183 nuclear reactors in shutdown condition. In the United
Stated there are 73 license renewals approved, 14 are under review and 9 NPP send a letter of intent to apply for a license renewal (WEC, 2007).

The NPP lifetime extension affects operation and maintenance strategies, decommissioning schedule and strategy, radioactive waste management and disposal requirements. It also has an impact on a country's overall nuclear energy program.

Licensed service life of nuclear reactors has been originally planned for up to 40 years. However, it was concluded on the basis of periodic safety reviews, that NPPs service life could be extended up to 50 to 60 years. Different countries have different policies, but it is quite common to renew the license every 10 years, after the NPP is examined and is found to comply with the requirements.

\section{Regulatory Topics for Power Uprate}

This section is a compilation of some regulatory issue for power uprate, is important to say that the operational experience obtained in the implementation of previous power uprate is main feedback to identify the most important safety issue.

\section{Operational Transients}

The evaluation of the most limiting operational transient should be performing. In particular for BWR the overpressure transient are the most limiting for the thermal limits and the evaluation of these should be performed each reload (Turbine trip with scram and fast closure of main steam insolation valves with scram). For power uprate without change in the dome pressure is not necessary change the setpoints of the Safety Relief Valve (SRVs), but is the dome pressure is increment the change in the SRVs setpoint should be considered in the transient analysis.

\section{Increase of Core Density Power}

The additional energy needed to increase the power are meet by increase of the enrichment of the bundle enrichment and the size of the reload fuel batch size. The power uprate operational conditions have a small impact in the thermal limits and the percent level for monitoring of thermal limits may change due to the uprate.

\section{Stability}

One of the strategies to increase power is the utilization of nuclear fuel with higher enrichment, therefore the first cycle after the implementation of power uprate, the core has a mix composition of fuel and the void fraction distribution can be different and the possibility of core oscillation is present. The reactor core and associated coolant, control and protection systems shall be designed to assure that power oscillations which can result in conditions exceeding specified acceptable fuel design limits are not possible or can be reliably and 
readily detected and suppressed. The use of high efficiency fuels in the power up rate permit reactor operation in an extended operation domain with increased void and thereby increased void reactivity feedback and which often have thinner fuel rods and thereby decreased response times, has resulted in a decrease of the stability margin in the low-flow, high-power region of the operating map (March-Leuba and Rey, 1993).

\section{Instrumentation and Control}

Changes in the variable process due to the implementation of the power uprate should be identified. For instance, the neutron monitoring system is affected by the increase of void fraction and the radiation levels in BWR and the instrument power signal are recalibrated to read $100 \%$ at the new licensed power. The instrumentation potentially affected by the EPU conditions is evaluated for changes in calibration. Examples of these instrumentation are: Feedwater flow and ultrasonic flow meters, Main Steam Lines (MSL) low pressure switches, MSL high flow trip units, turbine first stage pressure switches and process radiation monitoring.

\section{Control Rod Scram}

For power uprate with increase of the dome pressure, the hydraulic control unit of the Control Rod Drive System (CDR) should be modified in order to provide the additional pressure to move the control rods and complete the scram of the reactor. The scram time is important to limit the increase of the thermal power peak in case of overpressure transients and protect the fuel. In power uprate without change in the dome pressure no additional changes in the CRD is needed.

\section{Reactor Vessel Embrittlement}

The embrittlement of the reactor vessel wall adjacent to the core (beltline) is caused by neutron exposure. The power uprate results in higher neutron flux that reduces the plant life, therefore the analysis of this point are oriented to assure the margin of safety against fracture (NRC, 1995). Kryukov et al. (2012) studied the embrittlement of reactor pressure vessel steel with low concentration of cooper and phosphorus under very high neutron fluence.

\section{Rector Internal Vessel}

The increase of steam flow may produce higher loads in the reactor internal vessel in BWRs. The estimation of acoustic and flow-induced loads should be evaluated (Hambric et al., 2006; Moigne et al., 2008). Some of the component to considered in this part are: core shroud, steam dryer, control road mechanism, jet pumps assembly, cooling spray nozzles, among others.

\section{Steam Dryer Performance}

See section 7 of this study.

\section{Residual Heat Removal}

The residual heat removal system is designed to maintain the reactor coolant inventory and remove decay heat after a transient, LOCA, accident or normal shutdown. The safety evaluation of this topic is the result of higher decay heat in the core due to the power uprate and the increase of heat discharged into the containment after a LOCA.

\section{ECCS Performance}

The Emergency Core Cooling System (ECCS) are required to provide core cooling for all kind of LOCA events, but in case that the power uprate without change in the dome pressure, additional safety evaluation of the ECCS is not needed. On the other hand, if the power uprate involves the change in the dome pressure of the reactor vessel, the ECCS of high pressure probably needs pumps with higher capability (NRC, 2007a; 2007b).

\section{Increase of the Occupational Exposure Doses}

In service inspection of the piping increase the doses to the personal due to the increase of steam and feedwaterflow, in particular this problem is very important in BWR where occupational exposure is about $50 \%$ higher than PWRs. So a program oriented to reduce the doses after EPU implementation is of paramount importance. Probabilistic tools can be used to evaluate the most significant piping and welds and their contribution to the core damage in case of transient or accident. This kind of techniques allow a reduction in the numbers of inspect components until $90 \%$.

\section{Habitability of the Control Room}

The NPPs are designed to provide adequate radiation protection to permit access and occupancy of the control room under accident conditions without personnel receiving radiation exposures in excess of $0.05 \mathrm{~Sv}$ ( $5 \mathrm{rem}$ ) Total Effective Dose Equivalent (TEDE) for the duration of the accident. The power uprate results in an increment of the Source Term (ST), therefore a new ST analysis is needed to determinate if the habitability of the control rooms remains under design criteria after accidents that generally assume in their results a substantial meltdown of the core with subsequent release of appreciable quantities of fission products (NRC, 2009).

\section{Erosion/Corrosion of Pipes and Components}

Some BWR-4 has reported feedwater heater wall thinning and tube support damage producing steam and water leakage.

\section{Flow Induced Vibration}

The increase of flow on the reactor coolant boundary piping may produce additional vibration to be considered 
in the safety analysis. The most important points in this review are the structural evaluation of MSL, Feedwater (FW) and recirculation piping. In particular the MSL and FW lines have increase flow rate and flow velocities in order to accommodate the power uprate and consequently the vibrations increase due to turbulent flow that is proportional to the square of the flow velocity. Among the vibration events we can mention: for BWR-4 socket weld failure on zinc injection process skid, steam dryer damage, recirculation pump vibration, Electro Hydraulic Control (EHC) turbine control valve accumulator leaks, broken extraction steam line led to feedwater heater tube failure, EHC excessive vibration, for BWR5 feedwater heater tube leaks, steam dryer failure, for BWR3 steam dryer failure, MSL drain line failure and turbine stop valve pressure switches (BWROG, 2006). The most common failures associated with the power uprate are related with vibration in some components. Fujita (1990) studied the Flow-Induced Vibration (FIV) and Fluid-Structure Interaction (FSI) in nuclear power plant components, in particular for Pressurized Water Reactor (PWR).

\section{Containment Performance}

The containment response at power uprate conditions is reanalyzed to demonstrate the capability of this system under LOCA conditions, due to the blowdown flow rate depends of the initial conditions in the reactor vessel. The new peak containment temperature and pressure due to main steam like break is evaluated to determinate if these parameters are under design criteria. The initial analysis for the cooling water systems assumes scenarios with a single phase flow conditions, but with the power uprated two-phase flow condition due to a LOCA could be possible (Schueller and Ang, 1992).

\section{Probabilistic Risk Assessment (PRA)}

In order to evaluate the impact of the power uprate in the total Core Damage Frequency (CDF), the following areas are considered: initiating events, systems analysis, accident sequences, data analysis, human reliability analysis, dependence analysis, success criteria, structural analysis, thermal-hydraulic analysis. All the plant that implemented EPU have performed a PRA and have concluded that the CDF is not significant in comparison with the power increase, therefore a plant specific PRA update is not recommended. Other important parameter is the Large Early Release Frequency (LERF), that modeling of the core melts accident sequence progression, core-concrete interaction and containment failure. The impact on initiating event frequency, success criteria and the other parameters is insignificant. NRC of the United States has not set a specific acceptance criteria for the CDF and LERF increase associated with EPU. There are, however, criteria in Regulatory Guide which permits CDF change of less than per plant-year and LERF change of per plant-year, regardless of preEPU PRA results. RG 1.174 also permits CDF changes in the range of to per plant-year and LERF changes in the range of to per plant-year provided the pre-EPU CDF and LERF values are less than and per plant-year, respectively. The CDF and LERF increase due to an EPU has been about $10 \%$ or less over the base CDF. The increase in CDF and LERF values generally meet the RG 1.174 criteria. NRC of the United States has not set a specific acceptance criteria for the CDF and LERF increase associated with EPU (NRC, 2011).

\section{Power Uprate and Steam Dryer Failure}

Nuclear power plant components can be subjected to strong fluctuating loads and experience unexpected high-cycle fatigue failures while operating at EPU (Hambric et al., 2006). The EPU has been approved for BWR NPPs, with uprates ranging from $6.3 \%$ for Monticello in 1998 to $20 \%$ for Vermont Yankee in 2006. Some of these plants have not experienced major problems under EPU operating conditions. But in particular four NPPs, Quad Cities Units 1 and 2 (QC1 and QC2, respectively) and Dresden Units 2 and 3 with uprates in the range of 17 to $18 \%$, have experienced significant increases in flow-induced vibration in the MSLs and within the Reactor Pressure Vessel (RPV). The increased vibrations, along with increased fluctuating pressures within the steam, have led to damage of relief valves and steam dryers in the plants (Hambric et al., 2006).

The increase of steam flow due to EPU cause the pressure fluctuations acting on BWR steam dryers. The geometry of the steam lines, connections with the Safety Relief Valves (SRV) and the steam dryer hoods, may produce turbulent flow that induces random oscillating pressures on the dryer surface, with the magnitude of the pressures increasing with flow speed (Hambric et al., 2006). The turbulent flow also excites large-scale, lowfrequency acoustic modes in the RPV steam volume; these modes, in turn, oscillate against the dryer surface. Additionally, various acoustic disturbances in the main steam line, which are caused by turbulent flow, propagate through the steam impinges on the dryer and can be amplified by acoustic modes in the RPV. The excitation of mechanism of acoustic resonances has been studied in order to avoid severe vibrations and noise problems in nuclear reactor (Ziada and Shine, 1999; Ziada, 2010; NRC, 2004; Tulon, 2002).

In June 2002, a large cover plate on the outside of the original QC2 steam dryer broke off and pieces of the plate were carried by the steam through the MSLs. Before and after the failure, increases in moisture content in the MSL steam were evident, indicating that large cracks and/or holes in the dryer were allowing wet steam to flow directly into the MSLs. Exelon, the plant owner, installed thicker cover plates and used stronger welds to 
repair the dryer. However, in May 2003, moisture carryover in the MSL steam increased significantly again and the plant was shut down in June 2003 so the dryer could be inspected. This time, large cracks had formed through the walls of the dryer outer bank hood.

Regarding QC1 similar situation was experimented and in October 2003 the moisture content in the MSL steam increased. In November the same year, QC1 was shut down and a steam dryer inspection revealed that a portion of the outer bank hood had broken loose (about $16 \times 23 \times 1.3 \mathrm{~cm}$ ). While the steam dryers in the QC plants were cracking and breaking, valves on the MSLs were also experiencing higher vibration levels at EPU conditions. An Electrometric Relief Valve (ERV) on a QC1 MSL, along with several MSL support clamps and tie-back supports, failed in November 2003. The solution to this problem was the replacement of the steam dryer for a new one and the installing of Acoustic Side Branch (ASB) developed Continuum Dynamics Inc (CDI). Susquehanna 1 NPP replaced the steam dryer in order to avoid similar problems and some NPPs are planning the replacement of the steam dryer for a one of new generation with very low moisture carryover, these are: Browns Ferry 1, Monticello and Grand Gulf 1. CDI has a program to estimate the steam dryer load and employs an acoustic model to predict acoustic loads on the dryer from plant operational vibration data taken on the main steam piping. General Electric (GE) has a similar program where the steam dryer and piping for select plant are replicated in a scale model and then the acoustic loads measured are scaled to full size to determinate the total loads in the steam dryer.

The installation of an ASB modifies the resonance that exists in the standpipes connecting the MSLs to the safety relief valves. The addition of the ASB to the standpipe shifts the resonant frequency of the standpipe of the Safety Relief Valves (SRVs), thereby eliminating the acoustic standing wave generated by vortex shedding at EPU flow conditions. This provides a dampening effect on the acoustic energy input into the system.

Before replacing their steam dryers and installing ASB, Quad Cities Units 1 and 2 experienced repeated structural damage to their steam dryers and steam line components as a result of Extended Power Uprate (EPU) operation. Other Boiling-Water Reactor (BWR) licensees planning power uprates have predicted high pressure loading on their steam dryers and have modified or replaced their steam dryers. In addition to BWR plants, the Pressurized-Water Reactor (PWR) at the Palo Verde plant experienced degradation from excess vibration that had characteristics similar to those of the phenomenon affecting the BWR plants. The Table 1 resumes the current status of the steam dryer for BWRs.

The evaluation of steam dryer loads should be made before the implementation of EPU conditions and the modifications of steam dryer should be made based on the results of this evaluation (BWROG, 2006).

\section{Laguna Verde NPP (LVNPP) Power Uprate}

LVNPS 1 and 2 is a two units plant and is located on the coast of the Gulf of Mexico in the municipality of Alto Lucero in the state of Veracruz. Both units of this plant have a boiling water reactor nuclear steam supply system as designed and supplied by the General Electric Company and designated as BWR 5.

The primary containment is part of the overall containment system, which provides the capability to reliably limit the release of radioactive materials to the environs subsequent to the occurrence of the postulated Loss-Of-Coolant Accident (LOCA) so that offsite doses are below the "reference values" stated in Title 10 of the United States Code of Federal Regulations 10 CFR 50.67, Part 100 (NRC, 1999). The design employs the drywell/pressure-suppression features of the BWR/Mark II containment concept (CFE, 1979).

The Unit 1 started operation in 1990 and the Unit 2 in 1995 with rated power levels of $1931 \mathrm{MWt}$ each. The Unit 1 has been operated with a capacity factor of $80.73 \%$ and the Unit 2 with $85.34 \%$ and this NPP contributes with the $4 \%$ of the national electricity production. This station utilizes a single-cycle forced circulation BWR provided by General Electric (GE). The station is designed to operate at a gross electrical power output of approximately $695 \mathrm{MWe}$ and a net electrical power output of approximately $674 \mathrm{MWe}$.

The thermal power was uprated by $5 \%$ (from 1931 to $2027 \mathrm{MWt}$ ) during cycle 7 for unit 1 and cycle 4 for unit 2. In December of 1999 both units were authorized to operate to power uprate conditions. In July of 2008 the (CFE, 1979) (CFE-Mexican Electric Power Company) submitted the application to the Mexican Regulatory Authority (CNSNS) for an operate license at with a power level of $2317 \mathrm{MWt}$. This corresponds to $120 \%$ of the Original Licensed Thermal Power (OLTP) and this approach is referred as Constant Pressure Power Uprate (CPPU) due to for this EPU there is not change in reactor dome pressure.

The BWR are designed with SSC to accommodate steam flow rate at least $5 \%$ above the original rating. Safety analysis using better computer codes, methodologies and operation experience allow the increase the thermal power by $5 \%$ without any hardware modification in the Nuclear Steam Supply System (NSSS). However, the power increases up to $20 \%$ involve major changes in the SSC. Changes in the main condenser, turbine blades, main generator, steam reheater, booster pump with more capacity are some of the more important changes performed in LVNPP.

The steam dryer analysis is considered the critical path in the LVNPP power uprate project. The implementation of ASB in the standpipes of the safety relief valve was done in the last refuel for both Units (June of 2010 for U1 
and December of 2010 for U2) and up to now the steam dryer analysis for LVNPP still under review by the Mexican regulatory body. According with CNSNS the evaluation of the power uprate application for LVNNP required about 35-man years work.

The measurements provide information about the pressure fluctuations in the steam line where the strain gauges are installed. This data set was analyzed by using the technique of Short-Time Fourier Transform (STFT). This method is one of the most important time-frequency transformations introduced by Gabor (1946). It uses windowing to analyze a small section of the signal in time and it is defined by:

$S(u, v)=\int_{-\infty}^{\infty} x(t) g(t-u) e^{-i v t} d t$

where, $x(t)$ is the signal to analyze and $g(t)$ is a window whose energy is concentrated in the neighborhood of $u$. This window measures the evolution in time of the spectral content of $x(t)$.

The Heisenberg's uncertainty principle establishes that the maximum resolution, in the time-frequency plane, is limited by the product $\sigma_{t} \sigma_{\omega}$ satisfying:

$\sigma_{t} \sigma_{\omega} \geq \frac{1}{2}$

where, $\sigma_{t}$ and $\sigma_{\omega}$ are the time and frequency spreads, respectively, of the atoms obtained by translations in time and frequency of the window $g$ : $g_{u, v}(t)=g(t-u) e^{i v t}$

It can be demonstrated that the product $\sigma_{t} \sigma_{\omega}$ remains constant and that is the same for the entire time-frequency plane. The maximum resolution is obtained with a Gaussian window, where the atoms $g_{u}, v(t)$ are called Gabor functions.

The density of energy denoted as $P_{s}$ and obtained by:

$P_{s}=|S(u, v)|^{2}=\left|\int_{-\infty}^{\infty} x(t) g(t-u) e^{i v t} d t\right|^{2}$

Is called a spectrogram and measures the energy of the signal in the time-frequency neighborhood of $(u, v)$.

Application of the STFT allows to track in time the spectral content of analyzed signals. The choice of the window is important. This is due to the fact that the Fourier transform of this window represents its convolution in frequency with the spectrum of the analyzed signal. A rectangular window is not suitable for harmonic analysis where the frequencies in the analyzed signal are close to each other. Based on the results presented in (Harris, 1978), a good choice for this analysis may be a Hanning window. An overlap of $60 \%$ of these applied windows is used to avoid problems in the boundaries where magnitude of the data is attenuated due to the windowing.

The Fig. 1 shows the damping of the resonances at 148, 195 and $201 \mathrm{~Hz}$ in the main steam lines before (U2) and after (U1) the coupling of the ASB on the stand pipes of the SRV.
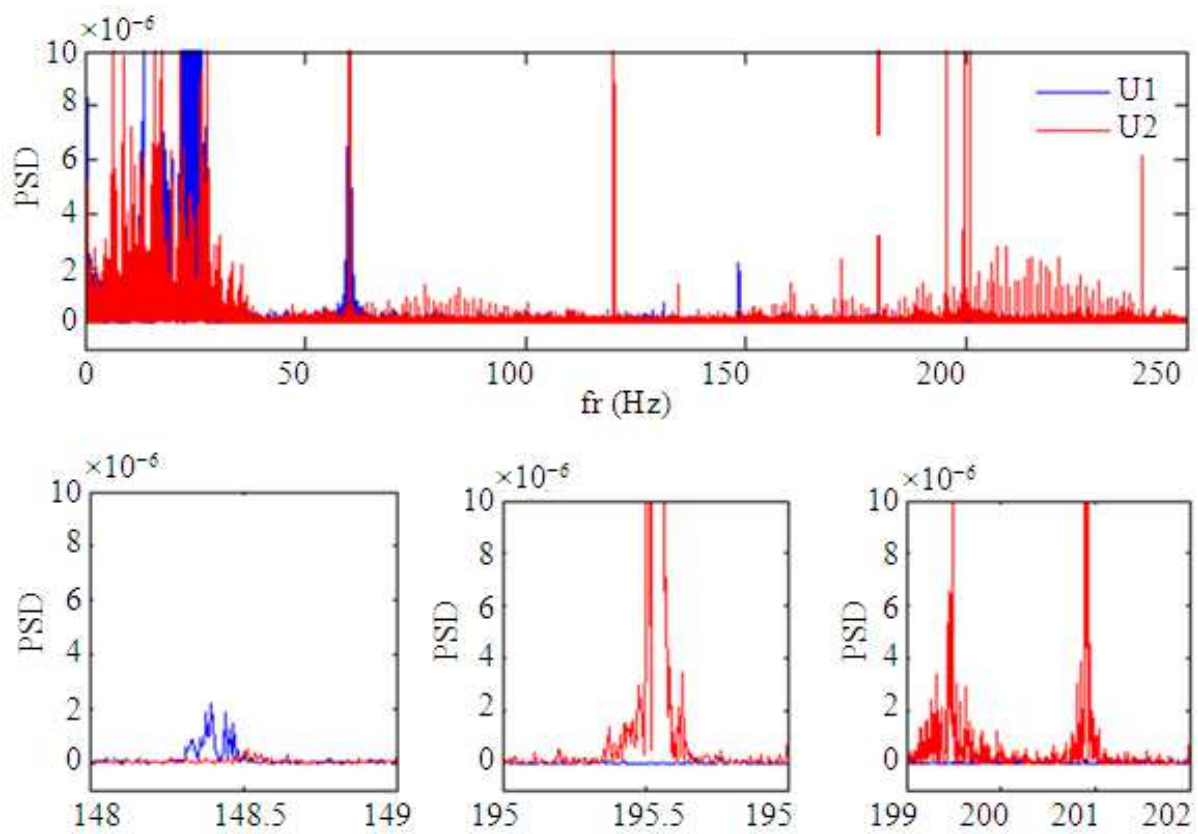

Fig. 1. PSDs before and after the connection of the ASB in the standpipes of the Safety Relief Valves (SRVs) 


\section{Conclusion}

Nowadays the population demands the generation of electricity with a low impact to the environment and the nuclear energy fulfills this requirement against climate change and the power uprate in NPPs represents a good option to save the high demand of electricity and is a common practice in the nuclear industry since 1979 . The most common power uprate is the stretch due to is not necessary major modifications to the NPP, but this implies important modifications in the plant operation and licensing basis documents. According with the Probabilistic Risk Assessment (PRA) result for power uprate, the increase in the core damage frequency and large early release frequency are very small and therefore is not recommended a specific PRA for power uprate conditions.

The vibrations due the increment of steam and feedwater flow are the most common problems related with power uprate, other important topic is the failure of the steam dryer due to the increase of high-cycle fatigue. However each power uprate represent significant changes in the operation and licensing basis document of the NPP. The experience obtained after the implementation of many power uprate is the main feedback to the regulatory authorities to focus the safety evaluation in the weak points observed on others NPP.

\section{Acknowledgement}

The authors would like to acknowledge Alfonso Prieto Guerrero of the Universidad Autonoma Metropolitana (UAM) for the fruitful discussions regarding the signal analysis.

\section{Funding Information}

This work was performed under the auspices of the Comisión Nacional de Seguridad Nuclear y Salvaguardias (CNSNS) and the Universidad Autonoma Metropolitana (UAM)

\section{Author's Contributions}

Alejandro Nuñez-Carrera: Conception and design of the manuscript, data analysis with Fast Fourier Transformation and interpretation of results drafting of the manuscript.

Ana Lidia Carreño-Padilla: Acquisition of data and Analysis and interpretation of data drafting of the manuscript.

Erick Gilberto Espinosa-Martínez: Conception of the design of the manuscript. Final approval of the version to be submitted and any revised version.

Raúl Camargo-Camargo: Reviewing it critically for significant intellectual content of the manuscript drafting of the manuscript.

\section{Ethics}

This article is original and contains unpublished material. The corresponding author confirms that all of the other authors have read and approved the manuscript and no ethical issues involved.

\section{References}

BWROG, 2006. Open meeting with the Boiling Reactor (BWR) Owners Group (BWROG) to discuss. Extended Power Uprate (EPU) lessons learned and recommendations, ML063310413 PROJ0691 NEDO-33159, Rev 0 2006-12-01 2006-12-11.

CFE, 1979. Final Safety Analysis Report (FSAR). México.

Ferng, Y.M., 2009. CFD investigating the influence of power uprate on impingement wear sites for the feedwater heater in the nuclear power plant. Nuclear Eng. Design, 239: 231-238. DOI: 10.1016/j.nucengdes.2008.09.011

Fujita, K., 1990. Flow-induced vibration and fluidstructure interaction in nuclear power plant components. J. Wind Eng. Ind. Aerodynam., 33: 405-418. DOI: 10.1016/0167-6105(90)90056-I

Gabor, D., 1946. Theory of communication. J. IEE, 93: 429-441. DOI: 10.1049/ji-3-2.1946.0074

Hambric, S.A., T.M. Mulcahy, V.N. Shah, T. Scarbrough and $\mathrm{C} . \mathrm{Wu}, 2006$. Flow-induced vibration effects on nuclear power plant components due to main steam line valve singing. Proceedings of the 9th NRC/ASME Symposium on Valve, Pumps and Inservice Testing, Jul. 17-19, USNRC, Washington, DC.

Harris, F., 1978. On the use of windows for harmonic analysis with the discrete Fourier transform. Proc. IEEE. 66: 51-83. DOI: 10.1109/PROC.1978.10837

IAEA, 2003. Safety margins of operating reactors IAEATECDOC- 1332. Int. Atomic Energy Agency.

IAEA, 2004. Implications of power uprates on safety margins of nuclear power plant IAEA-TECDOC1418. Int. Atomic Energy Agency.

Kim, T.W., V.N. Dang, M.A. Zimmermann and A. Manera, 2012. Quantitative evaluation of change in core damage frequency by postulated power uprate: Medium-break loss-of-coolant-accidents. Annal. Nuclear Energy, 47: 69-80.

DOI: $10.1016 / \mathrm{j}$.anucene.2012.04.021

Kryukov, A., L. Debarberies, U. Von Estorff, F. Gillemot and F. Oszvald, 2012. Irradiation embrittlement of reactor pressure vessel steel at very high neutron fluence. J. Nuclear Mater., 422: 173-177. DOI: $10.1016 /$ j.jnucmat.2011.12.026

Lundgren, K. and R. Riess, 2007. Consequences of power uprating. LCC3 Special Topic Report Consequences of Power Uprating, Sweden. 
March-Leuba, J. and J.M. Rey, 1993. Coupled thermohydraulic-neutronic instabilities in boiling water nuclear reactors: A review of the state of the art. Nuclear Eng. Design, 145: 97-111. DOI: 10.1016/0029-5493(93)90061-D

Martin, R.P., 2012. An evaluation methodology development and application process for severe accident safety issue resolution. Sci. Technol. Nuclear Installat, 2012: 13-13. DOI: 10.1155/2012/735719

Moigne, Y.L., A. Adrén, I. Greis, H. Kornfeldt and P. Sundlöf et al., 2008. BWR steam dryer for extended power uprate. Nuclear Eng. Design, 238: 2106-2114. DOI: 10.1016/j.nucengdes.2007.11.021

NEA, 2006. Nuclear power plant life management and longer-term operation OECD-NEA. Nuclear Energy Agency. DOI: 10.1787/9789264029255-en

NRC, 1995. Fracture toughness requirements, 10 CFR 50 Appendix G. Nuclear Regulatory Commission.

NRC, 1999. Accident source term. 10 CFR 50.67. Nuclear Regulatory Commission.

NRC, 2004. Aditional flow-induced vibration failure after a recent power uprate. Information Notice, Nuclear Regulatory Commission.

NRC, 2007a. 50.46 Acceptance criteria for emergency core cooling systems for light-water nuclear power reactors. 10 CFR 50.46. Nuclear Regulatory Commission.

NRC, 2007b. Appendix A to part 50-general design criteria for nuclear power plants, criterion 35, 10 CFR 50. Nuclear Regulatory Commission.

NRC, 2011. Regulatory Guide an approach for using probabilistic risk assessments in risk-informed decisions on plant-specific changes to licensing basis. Nuclear Regulatory Commission.
Ramírez, J.R., P. Enriquez, R. Castillo and G. Alonso 2012. MOX fuel use in a BWR with extended power up-rate original. Annal. Nuclear Energy, 50: 63-70. DOI: 10.1016/j.anucene.2012.07.008

Schueller, G.I. and A.S. Ang, 1992. Advances in structural reliability. Nuclear Eng. Design 134: 121-140.

Shin, C.H., T.H. Chun, D.S. Oh and WK. In, 2012. Thermal hydraulic performance assessment of dual-cooled annular nuclear fuel for OPR-1000. Nuclear Eng. Design, 243: 291-300. DOI: $10.1016 /$ j.nucengdes.2011.12.010

Tulon, J., 2002. Site vice president, exelon generation corporation, to nuclear regulatory commission. 2002. Reactor Shutdown due to Failure of Reactor Steam Dryer from Flow-Induced Vibrations as a Result of Extended Power Update, Licensee Event.

Wang, M.Y., T.K. Yeh and C.F. Chu, 2008. Predicted impact of power uprate on the water chemistry of Kuosheng boiling water reactor. Nuclear Eng. Design, 238: 2746-2753.

DOI: 10.1016/j.nucengdes.2008.05.007

WEC, 2007. The role of nuclear power in Europe. World Energy Council.

Ziada, S. and S. Shine, 1999. Strouhal numbers of flowexcited acoustic resonance of closed side branches. J. Fluids Struct., 13: 127-142. DOI: $10.1006 /$ jfls. 1998.0189

Ziada, S., 2010. Flow-excited acoustic resonance in industry. J. Pressure Vessel Technol., 132: 9-9. DOI: $10.1115 / 1.4000379$ 